\title{
The Influence of Study Habit, Peer Students' and Scholarship Utilization of BIDIKMISI Students' Learning Achievement in Economics Faculty Universitas Negeri Padang
}

\author{
Anisa Martiah ${ }^{1}$, Syamwil ${ }^{2}$ \\ 1 Universitas Negeri Padang, Padang, Indonesia, $₫$ anisamartiah@student.unp.ac.id \\ ${ }^{2}$ Universitas Negeri Padang, Padang, Indonesia, $\bowtie$ syamwil@fe.unp.ac.id
}

\begin{abstract}
The purpose of this study is to examine the influence of study habit, peer students' and scholarship utilization on learning achievement BIDIKMISI students', BIDIKMISI is a scholarships for students with low economic financial. This type of study is a quantitative descriptive. The sampling technique used proportional random sampling, so that obtained sample as much as 186 BIDIKMISI scholarship students' of 347 populations. The technique of data collection of this study uses the questionnaire. The technique of data analysis of this study uses path analysis by SPSS version16. The results of the study showed that: (1) the study habit has a correlation with peer students'. (2) The study habit and peer students' has a significant influence on scholarship utilization. (3) The study habit, peer students' and scholarship utilization has a significant influence on learning achievement.
\end{abstract}

Keywords : study habit, peer students', scholarship utilization, learning achievement

\section{Introduction}

Learning achievement is a benchmark in determining the success or failure of a learning process. Dobbins et al. (2016) Students' learning achievement has an important role in students' success in the future. Learning achievement is the result obtained by someone after having learning activities. Murtonen, Gruber, \& Lehtinen (2017) Learning achievement is the result of potential abilities possessed by someone that can be seen from behavior formed of knowledge mastery, thinking skills, and motor skills.

In learning process, someone always has desire or expectation to achieve the optimal results which is obtained for the sake of acquiring the high learning achievement. High values and GPA indicate that the students is able to attend the lecturing process optimally, instead of, less on values and GPA indicate that the student is not optimal in attending the lecturing process. Values and GPA are illustrated with high learning achievements which will have the great benefit to the students, as it will accelerate the college years periods, and it is easier to get educational scholarship (Riya \& Bani, 2015).

The Government of Republic of Indonesia (RI) since 2010 through the Directorate General of Higher Education has launched an educational scholarship program (Bisikmisi) for outstanding students'. BIDIKMISI is a scholarships for the student's with low economic financial and have a good academic potential to study in higher education in superior study programs (Pedoman BIDIKMISI, 2018). The Bidikimsi scholarships are evaluated its success through students' GPA that are obtained by the BIDIKMISI students' which is carried out at the end of each semester. BIDIKMISI students' are expected to maintain the minimum GPA, namely 3,00 during in eight consecutive semesters. If a BIDIKMISI students' cannot maintain the minimum GPA which has been set, the students' will be given a warning, guidance or dismissal of BIDIKMISI scholarship that she/he has obtained.

The problem of this study is that BIDIKMISI students' learning achievements have not reached the set of minimum standard criteria. There is about $25,5 \%$ of total BIDIKMISI students' who have GPA less than 3,00. Slameto (2010) High and low students' learning achievement can be influenced by study habit, peer students' and the cost of education. Dimyati \& Mudjiono (2006) Study habit is one of the factors that 
influence students' achievement. Djaali (2009) Study habit are ways or techniques that settle on students' when receiving lessons, reading books, doing assignments, and setting time for learning and for other activities that can support learning. Good study habit will help students' to master the subject matter and achieve high learning achievement, while poor study habit will make it difficult for students' to understand the subject matter, so that learning achievement becomes low. This is supported by research conducted by (Udeani, 2012) in his research stating that study habit have a positive effect on students' learning achievement.

The next factor that affects learning achievement is peer students'. Vardardottir (2013) in his research states that students' learning achievements are influenced by peer students. Mcewan (2003) There are benefits for students who have been around their peer students whose high learning achievements. Thus, peer students as a form to get support in order to be better person and more accomplished. This is supported by research conducted by (Arcidiacono, Foster, Goodpaster, \& Kinsler, 2012; Feld, 2014; Giorgi et al., 2010) which the results of the research show that peer students are significantly influencing the students' learning achievements. However, Schreiner \& Bremer (2013) state that not all positive impact can be given by peer students, negative impacts also always follow when the diversity are occurred in. The influence of peers are more diminishing at the college students', therefore, peer students have a longstanding influence on learning achievement (Booij, Oosterbeek, Booij, \& Leuven, 2015; Brodaty \& Gurgand, 2016; Carrell et al., 2009). Furthermore, Astuti, Sumarwan, \& Qayim (2016) the results of this research found that external factors (peer students') do not significantly influence the learning achievement of BIDIKMISI scholarship recipients.

Another factor that affects learning achievement is the availability of tuition fees. Soraya \& Asriati (2013) in the research states that the availability of education costs has a positive effect on learning achievement (Elfindri \& Fitri, 2006). Declaring the funding of education to study in higher education is in the posts of tuition fees, entrance fees, living expenses, transportation, lodging, book costs, and research. Many efforts have been made by the government to assist the education fund in higher education, one of which is by providing scholarship. The use of BIDIKMISI scholarship can be used for academic purposes as well as to buy books, photocopies of assignments or lecture materials and lecture equipment used to support learning achievement. Rahayu \& Suwanda (2015) report that BIDIKMISI scholarship were 76.4\% allocated for academic needs, the rest were used for non-academic needs. This is supported by research of Nadiroh (2016) which states that the use of tuition assistance has an effect on student's learning achievement. Furthermore, research by Winnanda (2017) states that there is an indirect effect of giving scholarships to academic achievement through student learning motivation.

Based on phenomena above, it is considered to be an opportunity to develop knowledge, especially in the field of education in higher education. And this research will provide special benefits for educational institutions, policy makers, and the governments. Based on the above statements, this study aims to examine the influence of study habit, peer students' and scholarship utilization on learning achievement BIDIKMISI students' in Economics Faculty, Universitas Negeri Padang.

\section{Methods}

The type of research is quantitative descriptive research. Population in this research is received a BIDIKMISI scholarship of Faculty Economic Universitas Negeri Padang which amounted to 347 students' and sampling of 186 students' by using proportional random sampling. The data used are primary data and secondary data. Included in the primary data is the distribution of questionnaries to BIDIKMISI students' and which includes secondary data that is the student's GPA data obtained from the computer center of Universitas Negeri Padang.

Data collection technique used in this study are with using questionnaire distributed directly to respondents by using a likert scale. Before the research, validity test was conducted on the questionnaire 
that had been prepared by SPSS version 16. Validity test in this research was done by using correlation product moment technique that score of each item correlated with total score. Based on the result validity test of research known that indicator of study habit, peer students and scholarship utilization variable, there were 7 invalid items. Invalid item were thrown, because the valid statement already each indicators represent to continue the research. Once the validity level is determined proceed with the reliability test using the Cronbach's Alpha coefficient. Based on the result reliability test showed that the study habit has Crobach's Alpha of 0,930, peer students has Crobach's Alpha of 0,945, and scholarship utilization Crobach's Alpha of 0,893 . This is show that the instrument used is very high category and reliable.

Normality test is done by used Kolmogrov-Smirnov which aim to see whether the distribution of data is on the normal curve. Homogeneity test is done by used Levene test which aim to see if the data obtained came from a homogeneous sample. Data processing analysis techniques used in this research is path analysis. Path analysis in this study consist of two sub-structures. The first sub-structure to empirically test the influence of study habit, peer students on scholarship utilization. While the second sub-structure to empirically test the influence of study habit, peer students and scholarship utilization on learning achievement. This path analysis process using computer software SPSS version 16.

\section{Result and Discussion}

As explained earlier, the research was conducted by distributing questionnaries to 186 respondents. Based on the results of the research obtained data result of answer which than processed and tabulated that show the frequency distribution and percentage of answer BIDIKMISI students Economic Faculty of Universitas Negeri Padang with Respondent Level of Achievement, the results are as follows.

Table 1 The Frequency Distribution of Variables

\begin{tabular}{ccccc}
\hline No & Variable & Average & $\begin{array}{c}\text { Respondent Level of } \\
\text { Achievement }(\%)\end{array}$ & Category \\
\hline 1 & Study Habit & 3,84 & 76,82 & Good \\
\hline 2 & Peer Students & 3,88 & 77,76 & Good \\
\hline 3 & Scholarship Utilization & 3,67 & 73,52 & Good \\
\hline
\end{tabular}

Source: Primary data processed result, March 2019

Based on the result of descriptive analysis, it is known that the Respondent Level of Achievement of the study habit, peer students and scholarship utilization variables are in good category. This show that the respondent answer are able to describe each indicator in the variable well.

The results of the normality test are known that the data used in this study has been normally distributed, that is with the asymp value. Sig. (2-tailed) of $0,977>0,05$. Based on the result of homogeneity, it is known that the data study habit obtained a significance value of $0,728>0,05$, peer students obtained a significance value of $0,205>0,05$ and for the data scholarship utilization obtained a significance value of $0,292>0,05$. This show that the data is homogeny.

The coefficient of determination test $\left(\mathrm{R}^{2}\right)$ was used to assess the influence of certain exogenous variables on endogenous variables. The results coefficient of determination test are as follows.

Table 2 Results Coefficient of Determination Test $\left(\mathrm{R}^{2}\right)$

\begin{tabular}{cc}
\hline Variable & ${\text { Value } \mathrm{R}^{2}}^{2}$ \\
\hline Learning Achievement $(\mathrm{Y})$ & 0,431 \\
\hline Scholarship Utilization $\left(\mathrm{X}_{2}\right)$ & 0,195 \\
\hline
\end{tabular}

Source: Primary data processed result, March 2019 
Based on the result coefficient of determination test $\left(R^{2}\right)$ of learning achievement equal 0,431 . This mean that learning achievement BIDIKMISI students can be explained by the study habits, peer student and scholarship utilization of $43,1 \%$, while the remaining $56,9 \%$ is explained by other variables not examined in the model. Coefficient of determination $\left(R^{2}\right)$ scholarship utilization 0,195. This mean that scholarship utilization can be explained by study habit and peer student of $0,195 \%$ while the remaining $80,5 \%$ is explained by other variables not examined in the model.

Hypothesis testing aim to answer the existing problem in this study. The first test was aims to examine the correlation of between exogenous variable, such as to test of correlation study habit with peer student. The results are as follows.

Table 3 Result Correlation Test

\begin{tabular}{llrr}
\hline & & Study Habits & Peer Students \\
\hline Study Habit & Pearson Correlation & 1 & $.364^{* *}$ \\
\cline { 2 - 4 } & Sig. (2-tailed) & & .000 \\
\hline Peer Students & Pearson Correlation & $.364^{* *}$ & 1 \\
\cline { 2 - 4 } & Sig. (2-tailed) & .000 & \\
\hline
\end{tabular}

Source: Primary data processed result, March 2019

Based on the result of correlation testing reveal of value $\mathrm{r}_{\text {count }} 0.364>$ rtable 0.121 with a significance level of 0.000 which is lower than alpha 0,05 . his shows that Ha is accepted and Ho is rejected. in other words, study habits has a correlation with peer students. And the correlation value explain that the correlation of study habit with peer students is at the level of weak correlation.

The next testing hypothesis, that testing the influence exogenous variables on endogenous variables. The first stage of analysis was aimed at examining the influence of study habit and peer students on utilization scholarship. The result are as a follows.

Table 4 The Result of F test

\begin{tabular}{llcccc}
\hline Model & & Sum of Squares & Mean Square & F & Sig. \\
\hline \multirow{2}{*}{1} & Regression & 478.599 & 239.300 & 19.812 & $.000^{\mathrm{a}}$ \\
\cline { 2 - 6 } & Residual & 1980.898 & 12.079 & & \\
\cline { 2 - 5 } & Total & 2459.497 & & & \\
\hline
\end{tabular}

Source: Primary data processed result, March 2019

Based on result path analysis reveal an $\mathrm{F}_{\text {count }}$ value of 19,812 with a significance level of 0,000 which is lower than 0,05. This show that Ha is accepted and Ho is rejected. In other words, study habit and peer students have a significant simultaneous influence on utilization scholarsip. And further the partial analysis.

Table 5 The Result of Path Coefficient

\begin{tabular}{|c|c|c|c|c|c|c|}
\hline \multirow[b]{2}{*}{ Mode } & & \multicolumn{2}{|c|}{ Unstandardized Coefficients } & \multirow{2}{*}{$\begin{array}{c}\text { Standardized } \\
\text { Coefficients }\end{array}$} & \multirow[b]{2}{*}{$\mathrm{t}$} & \multirow[b]{2}{*}{ Sig. } \\
\hline & & B & Std. Error & & & \\
\hline \multirow[t]{3}{*}{1} & (Constant) & 19.547 & 4.145 & & 4.716 & .000 \\
\hline & Study Habit & .072 & .033 & .162 & 2.159 & .032 \\
\hline & Peer Students & .152 & .032 & .355 & 4.720 & .000 \\
\hline
\end{tabular}

Source: Primary data processed result, March 2019 
The result of partial analysis show that the influence of study habit on utilization scholarship has a path coefficient of 0,162 with significance level of 0,032 which is lower than alpha 0,05. This show that study habit has a significant influence on utilization scholarship. This mean that, good study habit will affect the utilization scholarship. Students who have good study habit will be followed by the utilization of efficient scholarship to support learning activities. In other words, if study habit are good then the pattern of utilization of scholarship is better.

Futher, the result show that the influence of peer students on utilization scholarship has a path coefficient of 0,355 with significance level of 0,000 which is lower than alpha 0,05 . This mean that peer students has a significant influence on utilization scholarship. The good peer students will influence the students to utilize the scholarship efficiently. Peer students will provide encouragement or support in learning, for example, making their friends to ask questions about how to manage finances well, and remind each other about using money efficiently so that tuition assistance (scholarship) can be utilized efficiently.

This finding is supported by the opinion Chotimah \& Rohayati (2015) of peer students greatly influencing the financial management of students because peer students can become informants, carers and financial advisors. (Falahati \& Paim, 2011) students who are always depend on and make their peer students as a source of information will make these students' encounter the difficulties in financial management. The results of this study supported by previous research conducted by Wulandari \& Hakim (2013) who states that peers have a significant positive effect on students' financial management behavior.

Based on these findings, the role of peer students can make the scholarship utilization more efficient. Indirectly, scholarship utilization is a variable that intervenes in improving the BIDIKMISI students' learning achievements.

This study then continued with the second stage of analysis which was aim at examining the influence of study habit, peer students and utilization scholarship on learning achievement. The results are as follows.

Table 6 The Result $F$ test of Exogenous to the Endogenous Variable

\begin{tabular}{llcccc}
\hline Model & & Sum of Squares & Mean Square & F & Sig. \\
\hline \multirow{2}{*}{1} & Regression & 4.353 & 1.451 & 41.174 & $.000^{\text {a }}$ \\
\cline { 2 - 5 } & Residual & 5.745 & .035 & & \\
\cline { 2 - 5 } & Total & 10.098 & & & \\
\hline
\end{tabular}

Source: Primary data processed result, March 2019

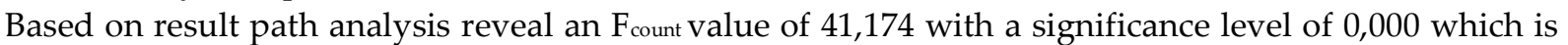
lower than 0,05. This show that Ha is accepted and Ho is rejected. In other words, study habit, peer students and utilization scholarship have a significant simultaneous influence on learning achievement. And further the partial analysis.

Table 7 The Result of Path Coefficient on the Influence of Exogenous to the Endogenous Variable

\begin{tabular}{|c|c|c|c|c|c|c|}
\hline \multirow[b]{2}{*}{ Mod } & & \multicolumn{2}{|c|}{ Unstandardized Coefficients } & \multirow{2}{*}{$\begin{array}{c}\text { Standardized } \\
\text { Coefficients }\end{array}$} & \multirow[b]{2}{*}{$\mathrm{t}$} & \multirow[b]{2}{*}{ Sig } \\
\hline & & B & Std. Error & & & \\
\hline \multirow[t]{4}{*}{1} & (Constant) & .707 & .239 & & 2.965 & .003 \\
\hline & Study Habit & .006 & .002 & .224 & 3.478 & .001 \\
\hline & Peer Students & .008 & .002 & .301 & 4.453 & .000 \\
\hline & Utilization Scholarship & .022 & .004 & .337 & 5.114 & .000 \\
\hline
\end{tabular}

Source: Primary data processed result, March 2019 
The result of partial analysis show that the influence of study habit on learning achievement has a path coefficient of 0,224 with significance level of 0,001 which is lower than alpha 0,05 . This is show that study habit has a significant influence on learning achievement. This means that learning habit will determine the level of students' learning achievement. The better study habit, the higher the learning achievement, and vice versa. This findings are supported by Bhat (2016) the results of research report that study habit influence students' learning achievement.

Second, the result of partial analysis show that the influence of peer students on learning achievement has a path coefficient of 0,301 with significance level of 0,000 which is lower than alpha 0,05 . This mean that peer students has a significant influence on learning achievement. A good peer students will provide positive support in learning, like inviting learning together, reminding each other of learning, and doing positive things, so that they will be motivated in learning. Conversely, peer students who are not good will inhibit learning, so that the learning achievements obtained are low.

This finding is supported by opinions Paola \& Scoppa (2010) that peer students quality is an important determinant of academic achievement. Kang (2006) states that peer students contribute and benefit on learning outcomes. When having studying together or group learning, peer students will provide information assistance on subject matter, so that it will help students to improve their learning achievement. Furthermore, research by Carbonaro \& Workman (2016) results reported that there were peer students influences on learning achievement.

Third, the result of partial analysis show that the influence of utilization scholarship on learning achievement has a path coefficient of 0,337 with significance level of 0,000 which is lower than alpha 0,05. This shows that utilization scholarship has a significant influence on learning achievement. It means that scholarship that are used efficiently both for the purchase of other stationery, learning books and things that support learning activities will improve the students' learning achievements.

This finding is supported by the opinion (Wasahua, 2018) with BIDIKMISI scholarship utilization in terms of living costs and education costs received by students, it is proven that students have a positive influence on academic achievement. Furthermore, (Afrila, 2011) the allocation of BIDIKMISI scholarships has a positive and significant effect on the learning achievements of BIDIKMISI scholarship recipients.

\section{Conclusion}

Students' learning achievement has an important role in students' success in the future. Someone who has good learning achievement as well in affective, cognitive and psychomotor aspect will make it easier for students' to obtain scholarships and become more successful in pursuing careers in the work field.

Path analysis in this study explains the direct and indirect effects of learning achievement. First, study habit and peer students have an indirect influence on students' learning achievement through scholarships utilization. It shows that study habit and peer students' play a role in utilizing scholarship to encourage or to motivate students to learn. Second, study habit, peer students and scholarship utilization directly affect students' achievements.

\section{References}

Afrila, D. (2011). Pengaruh Pengalokasian Beasiswa BIDIKMISI, Lingkungan Teman Sebaya, Dan Kebiasaan Belajar Terhadap Hasil Belajar Mahasiswa BIDIKMISI Universitas Negeri Padang. Jurnal Ilmiah DIKDAYA, 13-30.

Arcidiacono, P., Foster, G., Goodpaster, N., \& Kinsler, J. (2012). Estimating spillovers using panel data, with an application to the classroom. https://doi.org/10.3982/QE145

Astuti, F. B., Sumarwan, U., \& Qayim, I. (2016). The Role of Student Engagement in the Success of Study of Scholarship Awardee Students of Bogor Agricultural University , Indonesia, 3(3), 106-114. https://doi.org/10.20448/journal.509/2016.3.3/509.3.106.114 
Bhat, Y. I. (2016). Academic Achivements and Study Habits of College Students of District Pulwama, $7(10), 19-24$.

Booij, A. S., Oosterbeek, H., Booij, A. S., \& Leuven, E. (2015). Ability Peer Effects in University : Evidence from a Randomized Experiment, (8769).

Brodaty, T., \& Gurgand, M. (2016). Economics of Education Review Good peers or good teachers? Evidence from a French. Economics of Education Review, 54, 62-78. https://doi.org/10.1016/j.econedurev.2016.06.005

Carbonaro, W., \& Workman, J. (2016). Intermediate Peer Contexts and Educational Outcomes: Do The Friends of Students' Friends Matter? Social Science Research. https://doi.org/10.1016/j.ssresearch.2016.02.005

Carrell, S. E., Fullerton, R. L., West, J. E., Angrist, J., Black, S., Dupas, P., ... Sam-, A. (2009). Does Your Cohort Matter? Measuring Peer Effects in College Achievement, 27(3).

Chotimah, C., \& Rohayati, S. (2015). Pengaruh Pendidikan Keuangan Di Keluarga, Sosial Ekonomi Orang Tua, Pengetahuan Keuangan, Kecerdasan Spiritual, Dan Teman Sebaya Terhadap Manajemen Keuangan Pribadi Mahasiswa S1 Pendidikan Akuntansi. Jurnal UNESA, (3).

Dimyati, \& Mudjiono. (2006). Belajar dan Pembelajaran. Jakarta: PT. Rineka Cipta.

Djaali. (2009). Psikologi Pendidikan. Jakarta: PT. Bumi Aksara.

Dobbins, K., Brooks, S., Scott, J. J. A., Rawlinson, M., Robert, I., Dobbins, K., ... Robert, I. (2016). Studies in Higher Education Understanding and enacting learning outcomes : the academic $\hat{a}^{\mathrm{TM}} \mathrm{s}$ perspective, 5079(April). https://doi.org/10.1080/03075079.2014.966668

Elfindri, \& Fitri, R. (2006). Berburu Beasiswa. Visi Media.

Falahati, L., \& Paim, L. H. (2011). Toward a framework of determinants of financial management and financial problems among university students, 5(22), 9600-9606. https://doi.org/11.5897/AJBM11.1293

Feld, J. (2014). On the Nature of Peer Effects in Academic.

Giorgi, B. G. De, Pellizzari, M., Redaelli, S., Cipollone, P., Rosolia, A., Bayer, P., \& Pintoff, R. (2010). Identification of Social Interactions through Partially Overlapping Peer Groups, 2(April), 241-275.

Kang, C. (2006). Classroom Peer Effects and Academic Achievement : Quasi-Randomization Evidence from South Korea, (August).

Mcewan, P. J. (2003). Peer effects on student achievement : evidence from Chile, 22, 131-141. https://doi.org/10.1016/S0272-7757(02)00005-5

Murtonen, M., Gruber, H., \& Lehtinen, E. (2017). The return of behaviourist epistemology: A review of learning outcomes studies. Educational Research Review. https://doi.org/10.1016/j.edurev.2017.08.001

Nadiroh, F. (2016). Pengaruh Pemanfaatan Bantuan Dana Pendidikan dan Motivasi Belajar Terhadap Hasil Belajar Mahasiswa S1 Pendidikan Ekonomi Angkatan 2012 Universitas Negeri Malang, 9, 2230.

Paola, M. De, \& Scoppa, V. (2010). Peer group effects on the academic performance of Italian students, (October 2014), 37-41. https://doi.org/10.1080/00036840701765478

Pedoman BIDIKMISI. (2018). Direktorat Jendral Pembelajaran dan Kemahasiswaan Kementrian Riset, Teknologi, dan Pendididkan Tinggi.

Rahayu, Q., \& Suwanda, I. (2015). Pola Penggunaan Beasiswa BIDIKMISI Pada Mahasiswa Di Fakultas Ilmu Sosial Universitas Negeri Surabaya Angkatan Tahun 2011. Kajian Moral Dan Kewarganegaraaan, 3(Volume 03 Nomor 03), 1160-1174.

Riya, \& Bani. (2015). Psychological factors affecting student "s academic performance in higher education among students, (1), 63-71.

Schreiner, R., \& Bremer, B. (2013). From natural variation to optimal policy? the importance of endogenous peer group formation, 81(3), 855-882. https://doi.org/10.3982/ECTA10168

Slameto. (2010). Belajar dan Faktor yang Mempengaruhinya. Jakarta: PT. Rineka Cipta. 
Udeani, U. (2012). The Relationship between Study Habits, Test Anxiety and Science Achievement. Journal of Education and Practice, 3(8), 151-158.

Vardardottir, A. (2013). Economics of Education Review Peer effects and academic achievement : a regression discontinuity approach. Economics of Education Review, 36, 108-121. https://doi.org/10.1016/j.econedurev.2013.06.011

Wasahua, T. (2018). Evaluation Policy on Assistance Program BIDIKMISI Higher Education in Private Kopertis Region Xii, 5(1), 1-7. https://doi.org/10.20448/journal.509.2018.51.1.7

Winnanda, T. (2017). Pengaruh Beasiswa BIDIKMISI Terhadap Prestasi Mahasiswa Melalui Motivasi Belajar di Universitas Maritim Raja Ali Haji, 12, 1-20.

Wulandari, \& Hakim, L. (2013). Pengaruh Love Of Money, Pendidikan Keuangan Di Keluarga, Hasil Belajar Manajemen Keuangan, Dan Teman Sebaya Terhadap Manajemen Keuangan Pribadi Mahasiswa. Jurnal Pendidikan Akuntansi, 03 No 03, 1-6. 